\title{
Simulation of Modeling Approach for Flood Condition and Proposed Flood Protection at Midstream of Chao Phraya River Basin, Thailand
}

\author{
Cham Tau Chia*, Mitani Yasuhiro, Ikemi Hiroaki \\ Graduate School of Civil and Structural Engineering, Kyushu University, Fukuoka, Japan \\ *Corresponding author: coreyhut@gmail.com, cham@doc.kyushu-u.ac.jp
}

Received April 03, 2015; Revised May 01, 2015; Accepted May 10, 2015

\begin{abstract}
Thailand flood has resulted in serious impact to downstream of Chao Phraya River. Study on midstream of Chao Phraya River Basin has rarely been conducted. This research focuses on midstream of Chao Phraya RiverBasin, which includes confluence of Nan River and Yom River, also confluence of Ping River and Nan River. Flood condition at midstream is simulated using coupling of 1D and 2D hydrodynamic model, MIKE FLOOD to understand the flood generation. The model is calibrated and validated using flood marks measured at study area and streamflow data received from Royal Irrigation Department (RID). Furthermore, scenarios of flood control at 3 rivers are simulated and Geographic Information System (GIS) is used to calculate the flood distribution area and flood volume. Subsequently, 2 kinds of suitable flood control measurements are proposed. Results shows flood control at midstream helps reduce the risk of reflooding or flood return from small streams and flood plain into starting of Chao Phraya River. However, flood volume before confluence of Ping River and Nan River, which is Bung Boraphet area will be increased. Therefore, the land use planning and regulation at area nearby Bung Boraphet need to be considered.
\end{abstract}

Keywords: reflooding, flood control, simulation

Cite This Article: Cham Tau Chia, Mitani Yasuhiro, and Ikemi Hiroaki, "Simulation of Modeling Approach for Flood Condition and Proposed Flood Protection at Midstream of Chao Phraya River Basin, Thailand." American Journal of Environmental Protection, vol. 3, no. 3 (2015): 84-94. doi: 10.12691/env-3-3-4.

\section{Introduction}

The 2011 flooding of Chao Phraya River in Thailand has resulted in serious damage to the country. The Ministry of Finance (2012) reported the total damage and losses from the 2011 floods in Thailand amounted to USD 46.5 billion. The Chao Phraya River Basin is often divided into upstream (Northern Thailand), midstream (Nakhon Sawan) and downstream (Chao Phraya Delta) according to hydrological features (Figure 1). There are some studies on downstream of Chao Phraya River Basin but midstream has rarely been conducted. For example, Oki (2012) clarified flood condition in downstream of Chao Phraya Basin and analyzed on damage situation, however flood condition of midstream was not clarified. Prajamwong (2009) explained flood condition in the lower Chao Phraya River Basin and mentioned some flood mitigation methods such as lowland as large retention storage. However, estimated flood storage volume for countermeasures has not been clearly indicated. Komori et al. (2012)concluded 2011 flood was caused by increased rainfall by $143 \%$ over doubled runoff during rainy season. The resulting flood destroyed water gates and broke levees, especially at the left bank of the upper Chao Phraya Dam, and led to uncontrollable flooding. Some countermeasures are proposed but the flood control at midstream is not in consideration. Kwak et al. (2012) estimated total flood volume in Chao Phraya River Basin by using modified remote sensing indices to near-real-time Moderate Resolution Imaging Spectroradiometer (MODIS) images. Flood volumes were calculated by using a proposed flood inundation level (FIL) model with the Digital Elevation Model (DEM) but proper flood control are not discussed.

Figure 2 shows the flood extent of 2011 flood event at Nakhon Sawan. In the midstream of the Chao Phraya River Basin, Ping River, Yom River and Nan River flow down from the mountainous areas of Northern Thailand and converge at Nakhon Sawan. Bhumibol Dam (reservoir capacity of 13.5 billion $\mathrm{m}^{3}$ ) was constructed on Ping River and Sirikit Dam (reservoir capacity of 9.5 billion $\mathrm{m}^{3}$ ) was constructed on Nan River for irrigation, power generation and flood control purposes. There are another 5 dams that had been constructed for Ping River, Wang River and Nan River watersheds, resulting in a total reservoir capacity, including the Bhumibol and Sirikit Dam reservoirs to 25 billion $\mathrm{m}^{3}$ (Komori et al. 2012). In 1991, Thai government planned to build Kaeng Suea Ten Dam (reservoir capacity of 1.15 billion $\mathrm{m}^{3}$ ) on Yom River but the plan was abandoned. It was then renewed in 2006 but still having debate with residents around the area and yet to construct.

This study simulates flood condition at Nakhon Sawan, which is located at midstream of Chao Phraya River Basin. 
In addition, it recommends suitable flood control measures through simulation of different scenarios to understand total flood volume need to be stored at midstream in order to ease the flood conditions at downstream. A coupling of $1 \mathrm{D}$ and 2D hydrodynamic model, MIKE FLOOD is used to simulate flood generation at midstream and quantitative flood control conditions. Subsequently, GIS is used to analyze effect of measures on the changes in flood volume and flood distribution area.

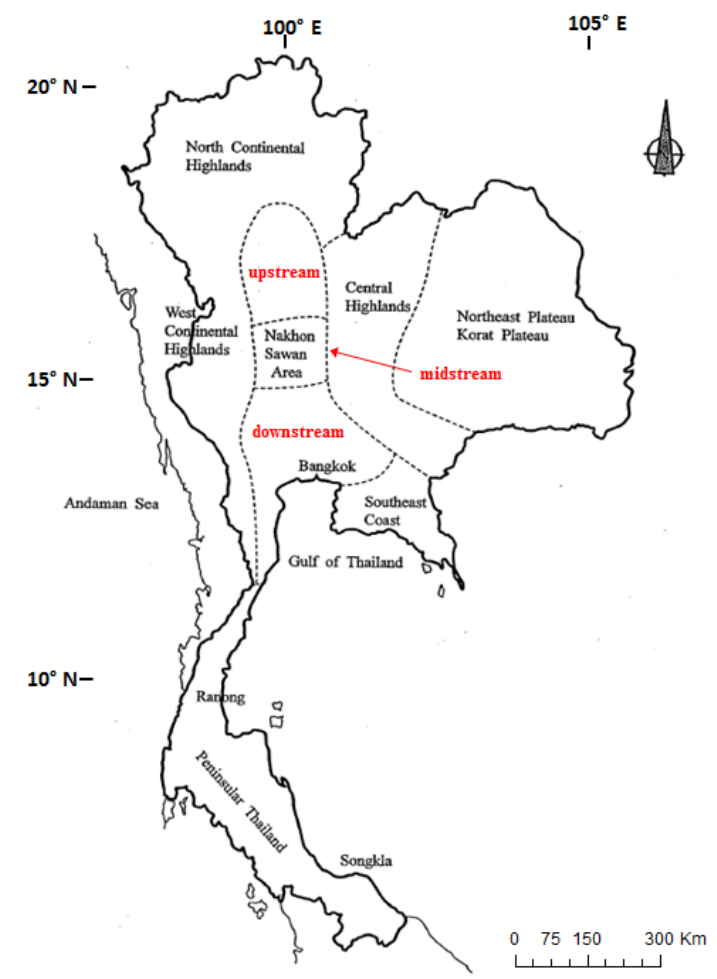

Figure 1. Chao Phraya River Basin in Thailand (source: CTI, 1999)

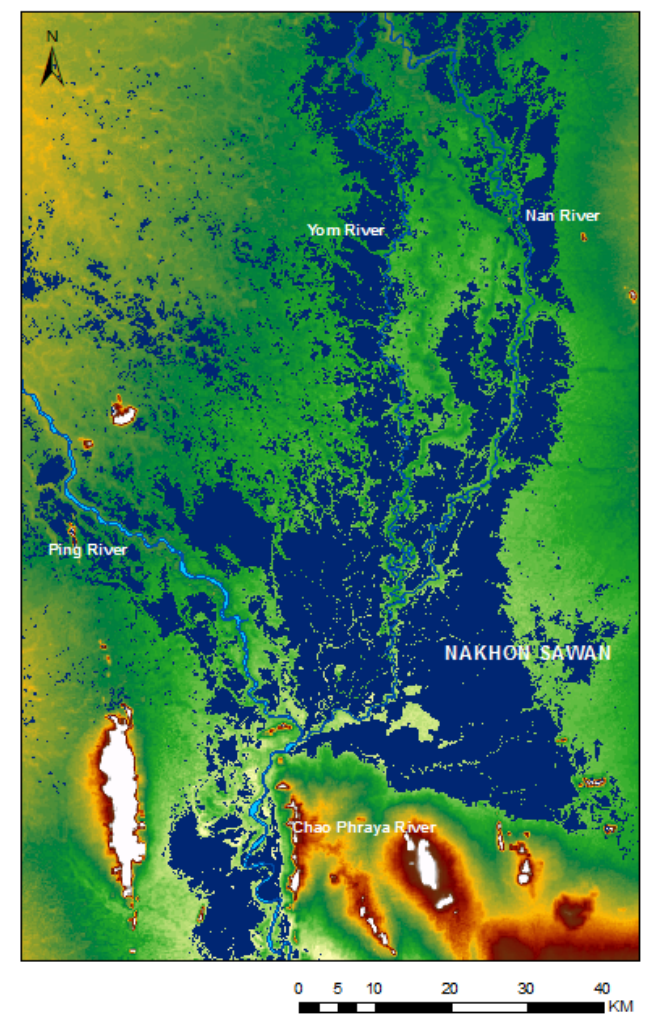

Figure 2. Floodextentat Nakhon Sawan (source from Royal Irrigation Department (RID)

\section{Study Area}

Figure 3 shows study area for this research. Those labeled in red are gauging stations. Nan River and Yom River converge at gauging station N.67. Ping River and Nan River converge before reaching gauging station C.2. Stream flow data of these gauge stations are received from Royal Irrigation Department (RID). Data of gauging stations at upper reach are used as input parameters for model, such as P. 7A, Y.17 and N. 7. Data of gauging stations at lower reach are used for validation, such as N.67 and C.2.

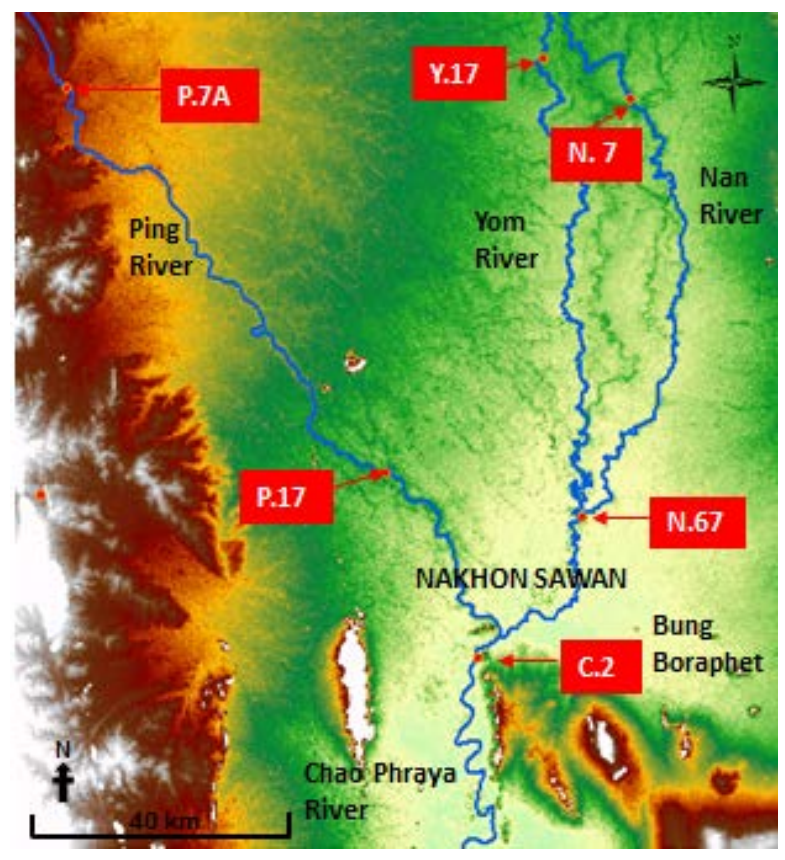

Figure 3. Location of gauging stations at Nakhon Sawan

\section{Simulation of 2011 Flood Condition at Midstream}

\subsection{Field Survey at Nakhon Sawan}

Flood marks investigations were conducted from September 27 to September 29, 2012. The flood marks investigation was conducted in surrounding area of Nakhon Sawan because most of the researches are focus on downstream and this study aims to understand the relationship between midstream with flood. Measurements of flood marks were conducted by using measuring rod. Since Digital Elevation Model (DEM) with coordinates of $\mathrm{X}, \mathrm{Y}$ and $\mathrm{Z}$ able to download from $\mathrm{U}$. S. Geological Survey (USGS), researchers use measuring road to obtain heights flood marks. Post processing would be done later to for flood volume calculation using GIS. Riverbanks, natural banks, back marshes, narrow segments and others are targeted areas because flood marks could be seen clearly in these locations. After post processing, a total of 8 flood marks are used for validation (Figure 4), which will be explained further in section 3.3.

\subsection{Calibration of Modelling}

Nedbør-Afrstrømnings-Model(NAM) Rainfall-Runoff model in MIKE 11 (DHI.co) has chosen for simulating 1D 
hydraulic modelling of rivers condition in study area. Streamflow data and Rainfall data in year 2011 for upper reach of Nan River, Ping River and Yom River are obtained from CTI. Rainfall data shows the volume of rainwater increase tremendously from mid of August. Streamflow data for gauging station Y.17, N.7 and P.7A are used as inflow boundary type for upper reach in model as these station are located at upper reaches of 3 main rivers. Projection of the model has defined as Universal Transverse Mercator (UTM) North 47 and cross sections are defined in each river. Cross sections data is obtained from International Centre for Water Hazard and Risk Management (ICHARM). Data is interpolated to have minimum 7 cross sections for each river. The simulation period for MIKE 11 is from April 1 to December 31, 2011 as limited period of streamflow data obtained.

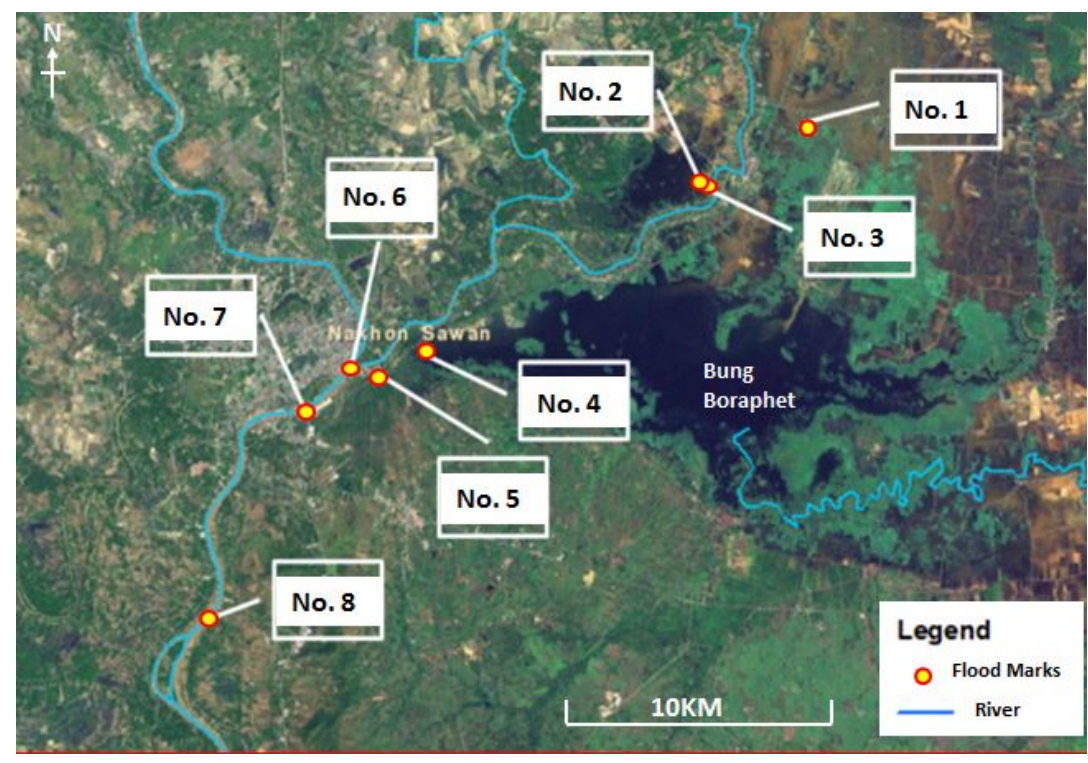

Figure 4. Location of flood marks

Furthermore, Shuttle Radar Topography Mission (SRTM) with resolution of 90mis used as bathymetry for MIKE 21 in 2D modelling. The SRTM was published in October, 2012. Finally, both 1D and 2D are coupled in MIKE FLOOD to simulate the flood generation. In the consideration of running time and quality of result, simulation period is focused from August 1 to December
30, 2011 with time step interval of 15 seconds. In this model, only parameters for main rivers (Nan River, Yom River, Ping River and Chao Phraya River) are included as limited data received. Simulation model did not include consideration of small streams around those main rivers. The results of model are discussed in next section.

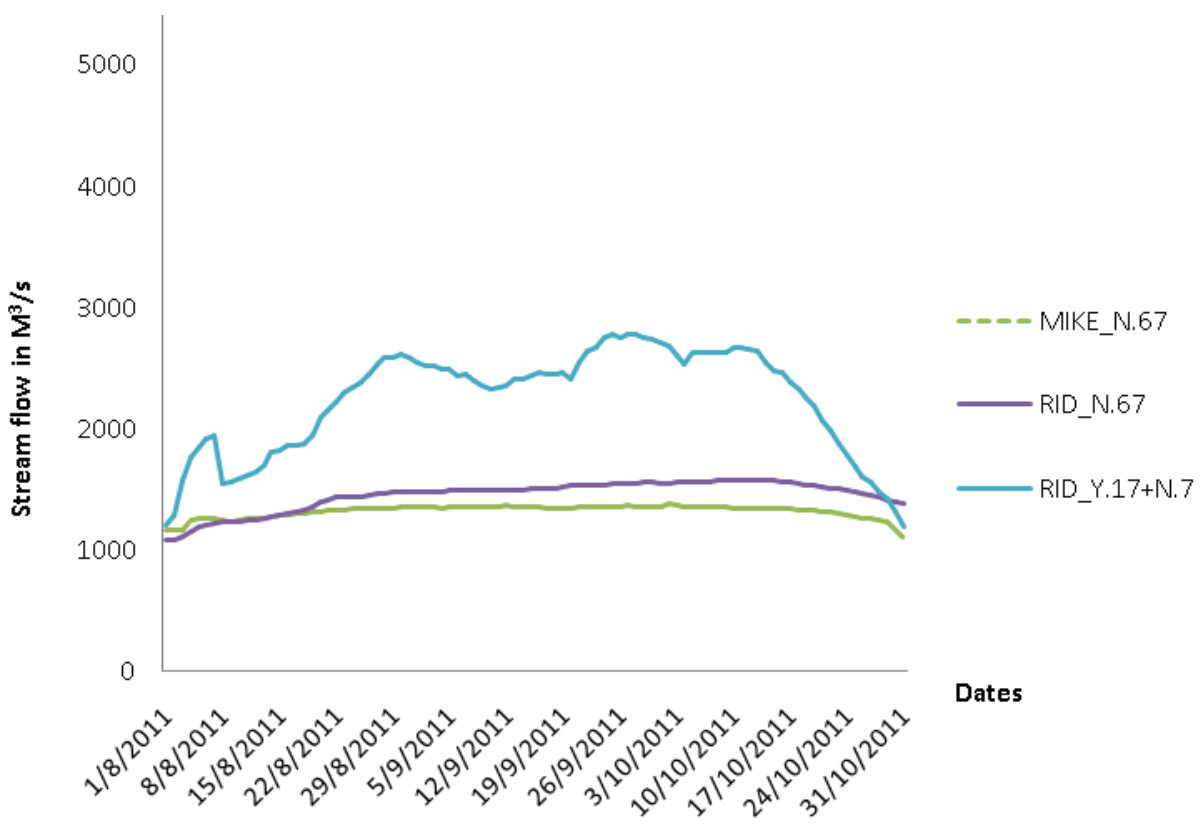

Figure 5. Streamflow result before and gauging station N.67

\subsection{Validation and Discussion}

Result of simulated streamflow is validated with data received from RID such as data at gauging N.67 and C.2.
Figure 5 shows the difference of streamflow before confluence of Nan River and Yom River (combination of data at gauging stations Y.17 and N.7) and after confluence of Nan River and Yom River (data at gauging 
station N.67). It also validates simulated result at gauging station N.67 with RID data.

From RID data, it is understood that flood condition before gauging station N.67 is more serious then after as there is difference nearly 63 hundred million $\mathrm{m}^{3}$ occurred. These flood amount flows into lower area, small streams and flood plain before reaching gauging station N.67 and ease the flood condition after gauging station N.67 as streamflow is less than $2000 \mathrm{~m}^{3} / \mathrm{s}$. Dotted line in Figure 5 represents the result of simulation at gauging station N.67 and it has about 10 hundred million $\mathrm{m} 3$ different with RID data in these 2 months. This amount could be flow into Nan River from small streams surrounding it as model only focused on main rivers.

In Figure 6, RID data at gauging station C.2 shows streamflow increases gradually from August. It reaches flood peak after September 21, which meant over its harmless streamflow limit of $4000 \mathrm{~m}^{3} / \mathrm{s}$. The total flood amount at gauging station C. 2 shows a big difference with gauging station N.67. This is caused by flood amount before gauging station N.67 returned and flowed back into Chao Phraya River (gauging station C.2). It became the reason of the flood peak occurred from September 21 to the end of October, 2011. When the simulated result from MIKE Flood is compared with RID data, it shows the same pattern of flow although it does not go up as smoothly as RID data. The different flood volume between simulated result and RID data is about 3 hundred million $\mathrm{m}^{3}$. It means flood volume at gauging station C. 2 only has 3 hundred million $\mathrm{m}^{3}$ affected by small streams surrounding it.

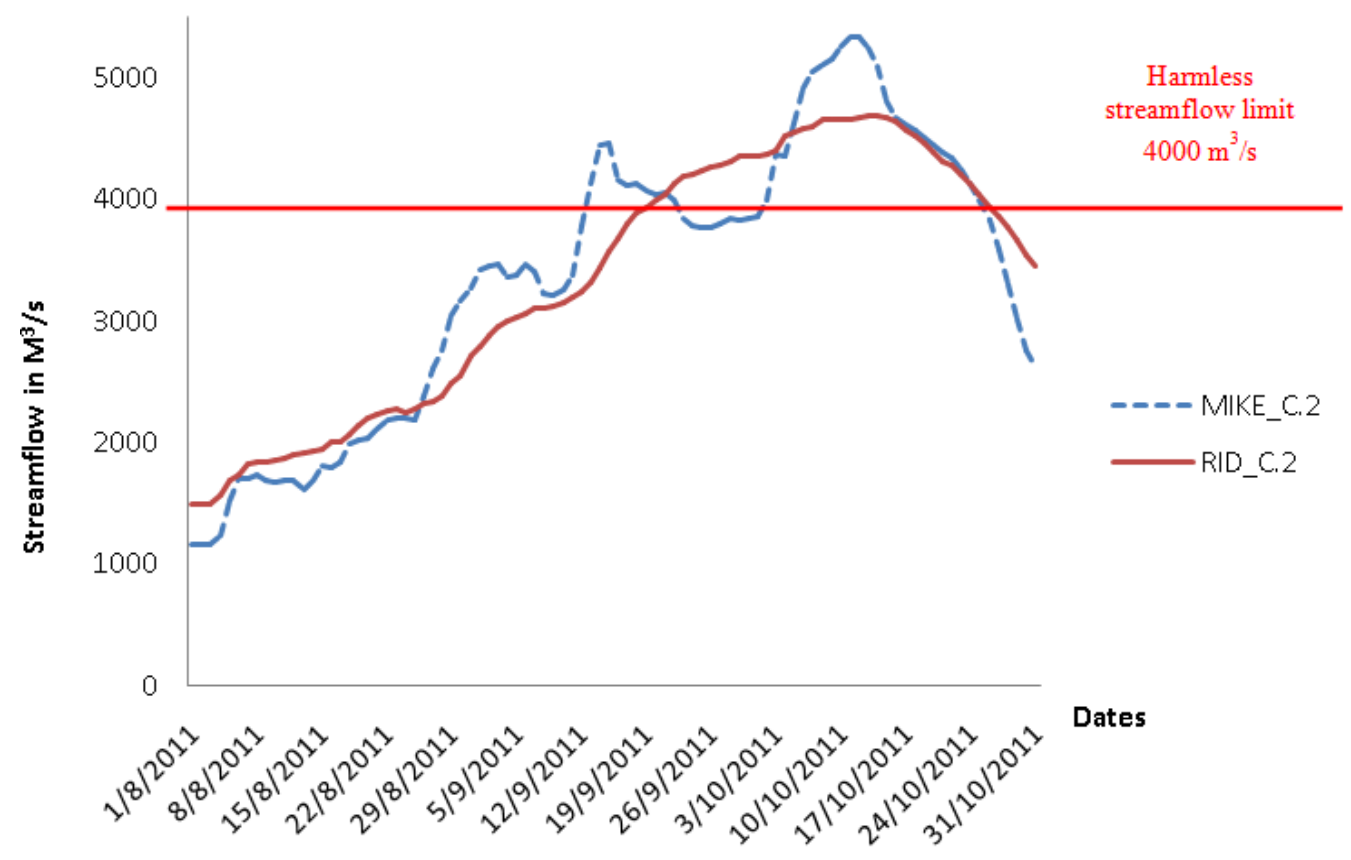

Figure 6. Streamflow after confluence of Ping River and Nan River, gauging station C.2

Therefore, if the reflooding or flood returned volume at upper reaches of Nan River and Yom River could be controlled, there is possibility to reduce the flood volume at gauging station C.2 over its harmless limit and minimize the flood risk at downstream of Chao Phraya River.

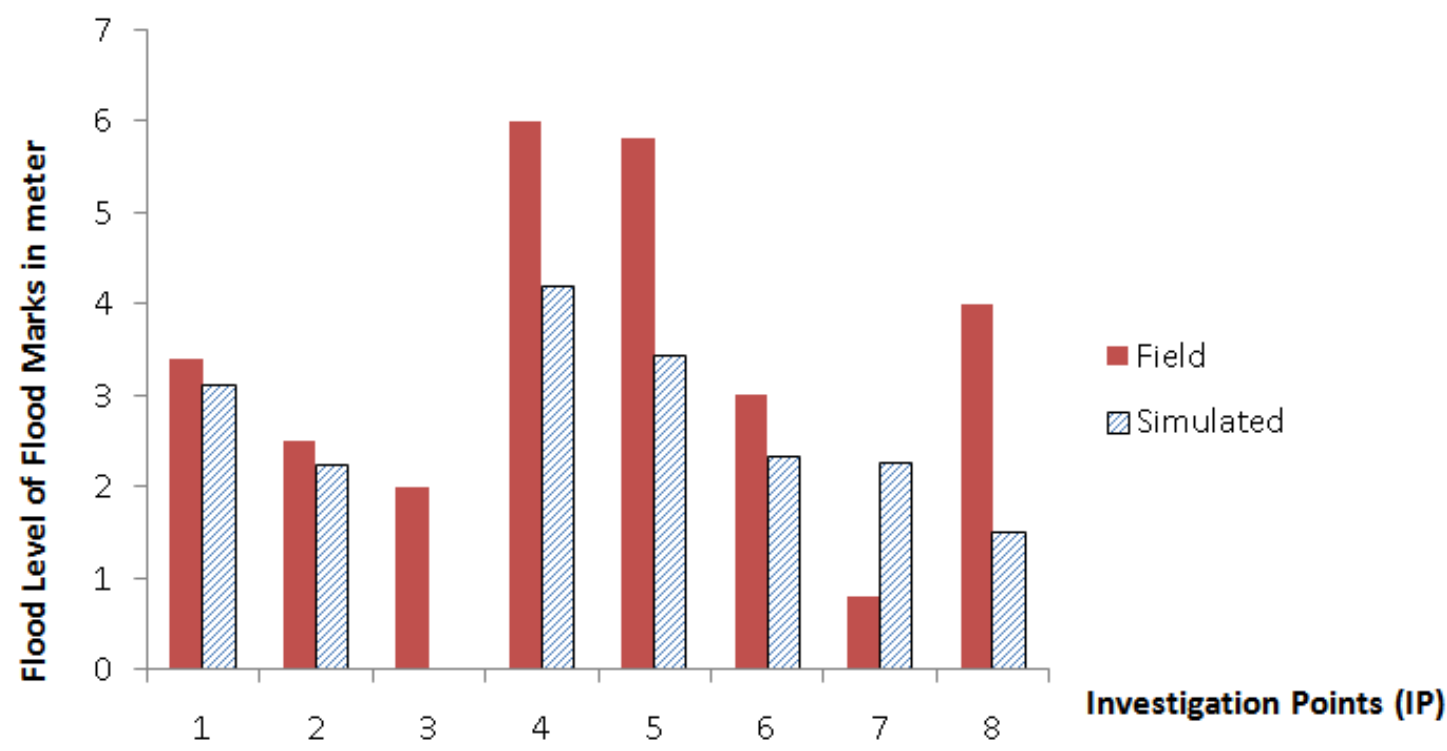

Figure 7. Comparison of flood level in between field investigations and simulated results 


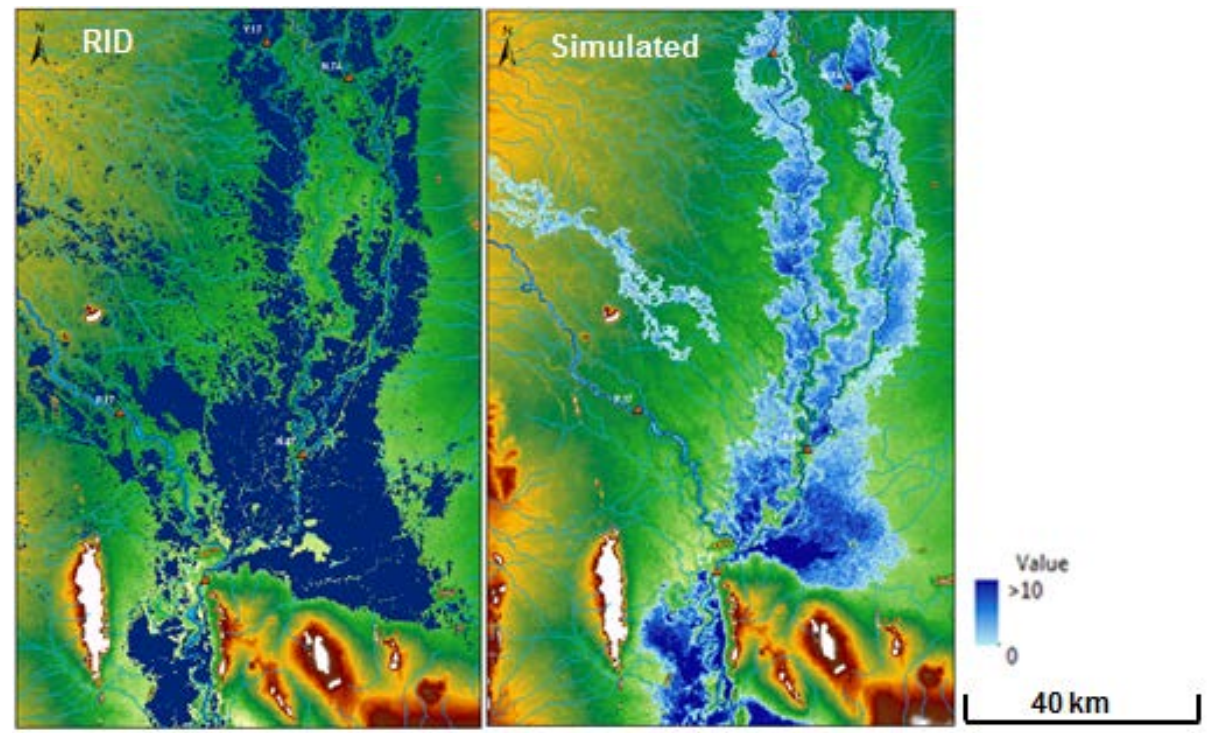

Figure 8. Comparison on flood condition at Nakhon Sawan between RID and simulated result on October 15, 2011

The flood inundation from the simulated result has validated with measurement of flood marks at Nakhon Sawan. The results are shown in Figure 7. Location of Investigation Points (IP) can refer to Figure 4. Among 8 points, IP 1, IP 2 and IP 6 are matched with different of \pm $0.5 \mathrm{~m}$. However, the resolution of Digital Elevation Model (DEM) has limited the accuracy and affected simulated result. IP 3 falls into dry area in model because the location is near to dike so it might be dike area in DEM. IP 7, which is location of a huge warehouse has different \pm $1 \mathrm{~m}$, it is near to Chao Phraya River so the location in model might be another side of warehouse. Besides, IP 4 and IP 5, which are at Bung Boraphet area has different \pm $2 \mathrm{~m}$, it might be affected by water level of Bung Boraphet in DEM.

Flood distribution on October 15, 2011 is compared between simulated result and flood extent of RID (see Figure 8). As simulation model did not include consideration of small streams around those main rivers, result of flood extent is smaller than RID. Total flood volume calculated in simulated result is about 3600 million $\mathrm{m}^{3}$. When flood volume of RID is estimated using spatial analyst in ArcGIS, it is about 4300 million $\mathrm{m}^{3}$. There is difference of 700 million $\mathrm{m}^{3}$ are considered flood volume caused by small streams.

\section{Flood Management Master Plan}

Thailand's flood management master plan is mainly divided to 2 types, the structural approach and the nonstructural approach. Structural approach includes measures to "store and divert" water and construction of floodways to divert water. Non-structural approach is to create "room for the river", which would increase areas for floods to promulgate. Reforestation is considered a part of the initiative to prevent rapid flooding in the upstream river basins. (Poaponsakorn et al, 2013)

Among variety of recommendations listed in comprehensive flood management plan, flood control operation on existing reservoir, reforestation or new reservoir will definitely help in controlling the flood volume at midstream before reaching downstream, which caused huge damage to Thailand. Reservoir Operation
Management for dams needs to be improved, particularly Sirikit dam located upper reach of Nan River and Bhumibol dam located upper reach of Ping River. Effects of flood control at Yom River are studied as Thai government plans to build a dam upper reach of Yom River. Effects of improvement on existing reservoirs on these 3 rivers will be discussed in section 5 .

\section{Flood Controlling at Midstream of Chao Phraya River Basin}

In this research, 3 scenarios quantified the benefits of flood control operation on existing reservoir and its potential to minimize flood risk. The simulated 2011 Thai flood event is evaluated in 3 scenarios. Parameters of streamflow data are modified in each case of scenario to predict conditions and effects when flood volume is under controlled at midstream. The hydraulic model is run repeatedly for each of the scenario cases.

Scenario 1 simulates the flood volume is controlled at upper reach of Nan River, Scenario 2 simulates flood volume is controlled at upper reach of Ping River and Scenario 3 simulates flood volume is controlled at upper reach of Yom River. The baseline of model (original) for comparison is validated model that calibrated with original parameters as discussed in section 3.3.

In order to choose the most applicable measures to control the flood condition, changes of streamflow along rivers and flood distribution are compared. Figure 9 shows the location of observation stations (Obs.) where changes of streamflow are observed. Table 1 is the list of cases and scenarios for flood controlling at different rivers.

\begin{tabular}{|c|c|c|c|}
\hline Scenario & Case & River Controlled & Condition \\
\hline \multirow[t]{3}{*}{ Scenario 1} & $1 \mathrm{a}$ & Nan & Reduced $10 \%$ flood volume \\
\hline & $1 \mathrm{~b}$ & Nan & Reduced $20 \%$ flood volume \\
\hline & $1 \mathrm{c}$ & Nan & Reduced 30\% flood volume \\
\hline \multirow[t]{3}{*}{ Scenario 2} & $2 \mathrm{a}$ & Ping & Reduced $10 \%$ flood volume \\
\hline & $2 b$ & Ping & Reduced $20 \%$ flood volume \\
\hline & $2 c$ & Ping & Reduced 30\% flood volume \\
\hline \multirow[t]{3}{*}{ Scenario 3} & 3a & Yom & Reduced $10 \%$ flood volume \\
\hline & $3 b$ & Yom & Reduced 20\% flood volume \\
\hline & $3 c$ & Yom & Reduced $30 \%$ flood volume \\
\hline
\end{tabular}




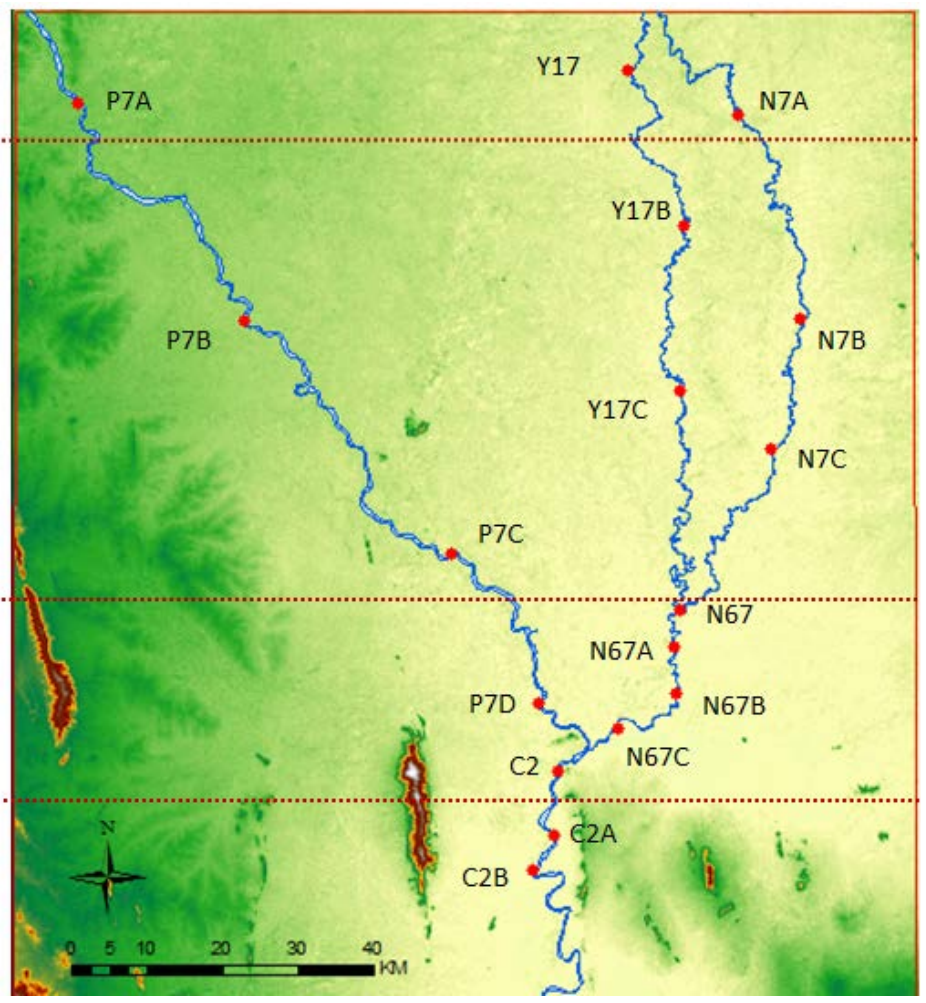

Figure 9. Observation stations (Obs.) for checking the streamflow condition

\subsection{Changes of Streamflow in 3 Scenarios}

Based on the streamflow data obtained from RID and flood generation in hydraulic model, flood peak started from the mid of September and the most serious flood extent was on October 15. Therefore, changes of streamflow on October 15 are compared for these 3 scenarios. Figure 10, Figure 11 and Figure 12 represent changes of streamflow in each different case in 3 scenarios.

When flood control is done at Nan River, streamflow of these 3 cases are lower than original before other rivers converged. The rate of lower streamflow is similar with the reduction rate of flood volume defined in simulation model. When Yom River converges with Nan River (from Obs.N67 to Obs.N67A), all cases still indicate streamflow lower than original. However, the reduction rate of water becomes lesser. When it reaches Obs.N67B and Obs.N67C, which is area near to Bung Boraphet, the streamflow is higher than original for all 3 cases. It means controlling the flood volume at upper reach of Nan River doesn't help to ease the flood condition at Bung Boraphet area. When Ping River converges with Nan River (from Obs.C2 to Obs.C2A), it doesn't bring much effect to it as the streamflow became lower than original. The rate of lower streamflow is similar to the reduction rate of streamflow before Obs. N67. Flood control at upper reach of Nan River results in minimizing the reflooding amount at Obs. C2, which is located at starting of Chao Phraya River. However, flood control cannot be done only at Nan River if amount of flood volume to be stored is about 10$30 \%$. If flood control is done only at Nan River, it helps to ease the flood condition along Nan River (from Obs.N7A to Obs.N7C) and after confluence of Ping River and Nan River (from Obs.C2A to Obs.C2BC) in minor effect. Conditions of other rivers will be analyzed in scenario 2 and scenario 3 to recommend the most suitable measures of flood mitigation.

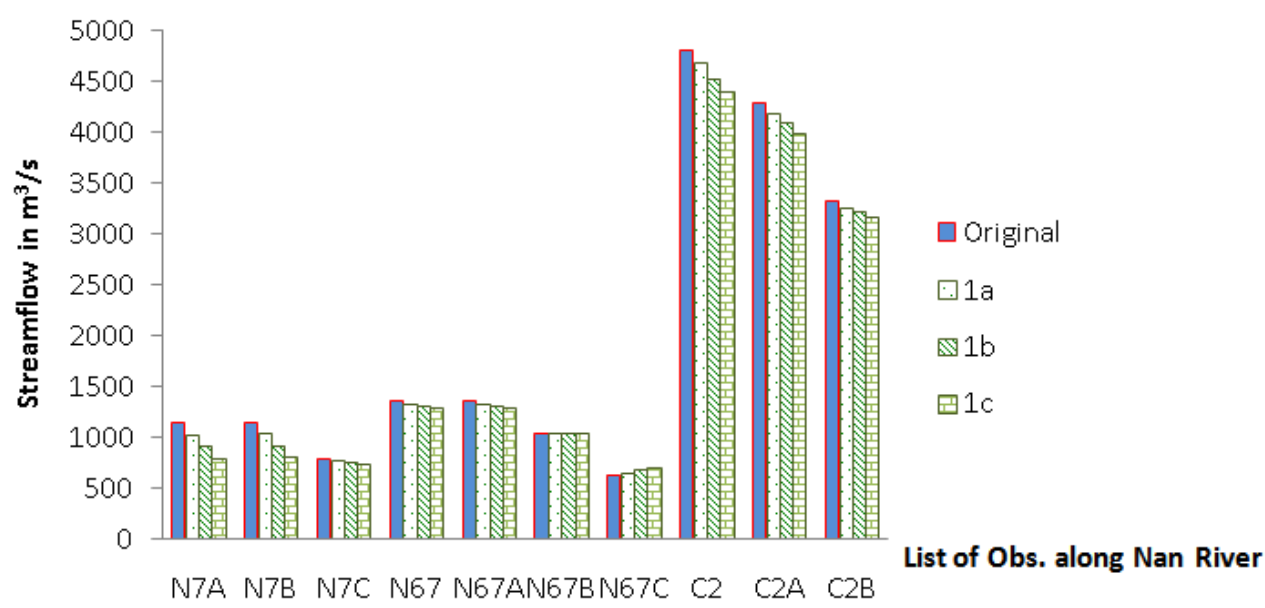

Figure 10. Changes of streamflow along Obs after flood controlled at Nan River, October 15 


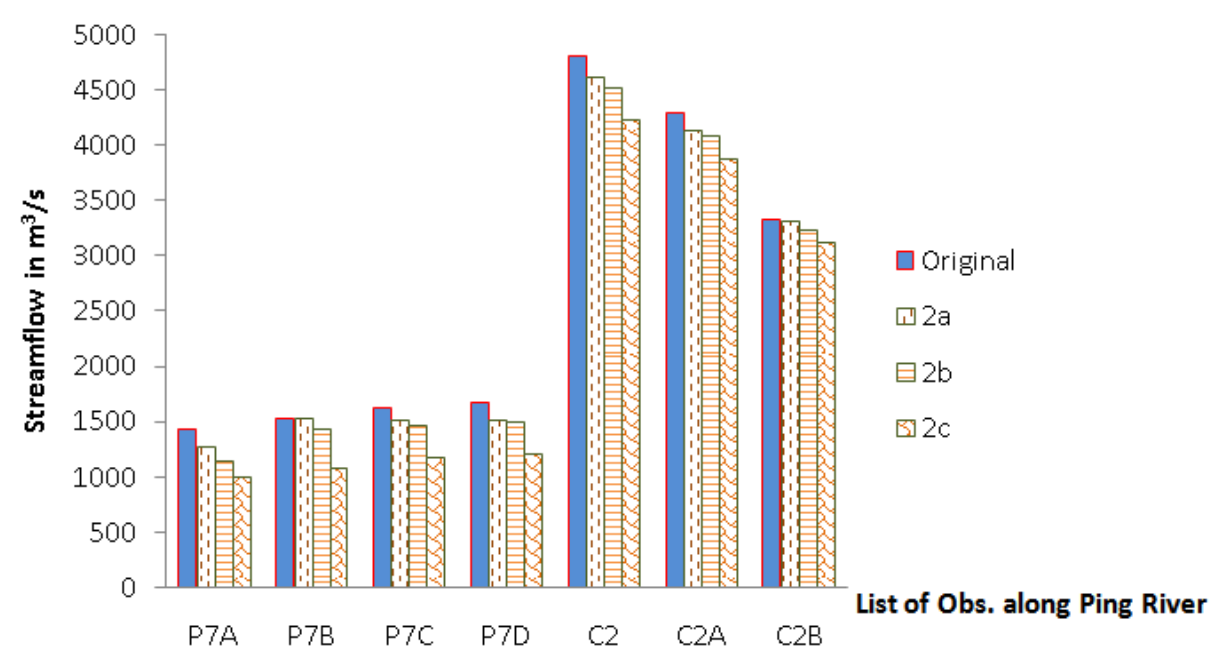

Figure 11. Changes of streamflow along Obs.after flood controlled at Ping River, October 15

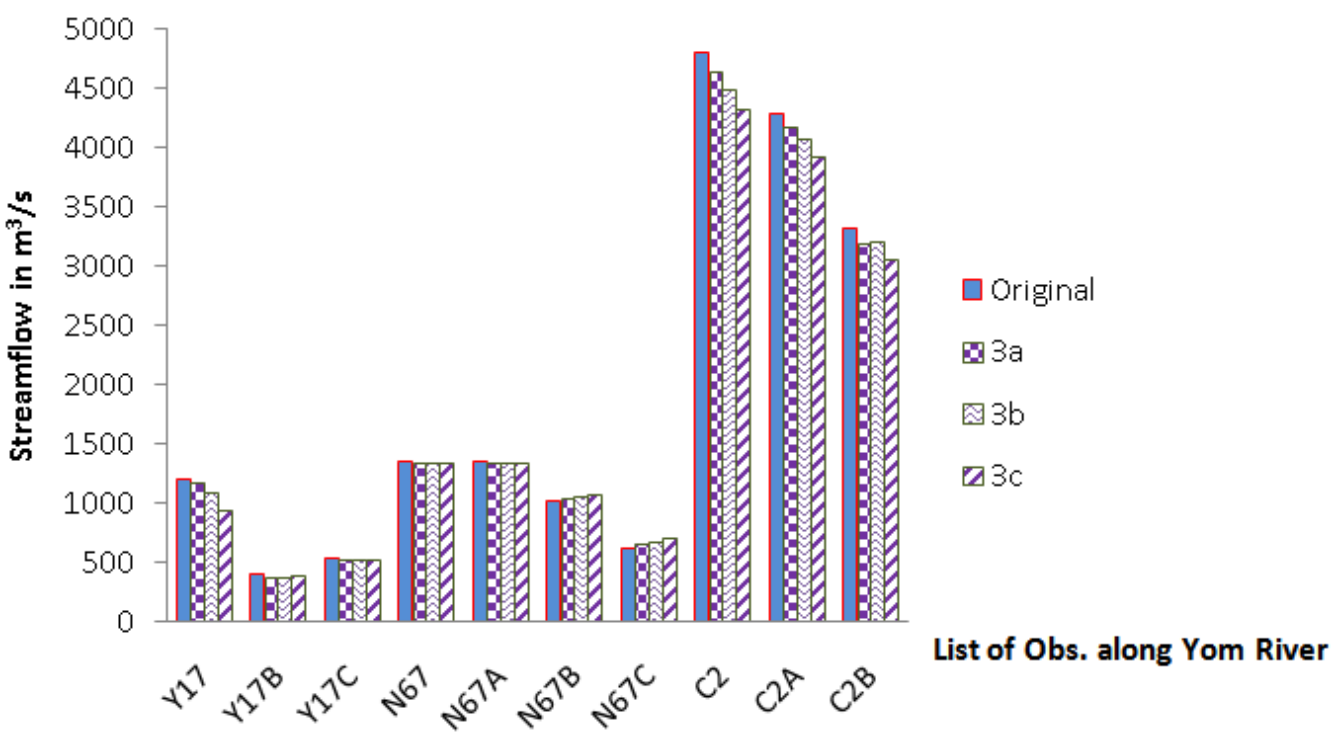

Figure 12. Changes of streamflow along Obs.after flood controlled at Yom River, October 15

Results of flood control at Ping River shows similar streamflow pattern along all Obs. When flood volume is stored at upper reach of Ping River, it affects directly along its river, whether before or after Obs. C2. The rate of lower streamflow also similar with the reduction rate of flood volume as defined in model except the end of Chao Phraya River (Obs. C2B) as it doesn't show much difference in these 3 cases. When flood is controlled, flood risk after confluence of Ping River and Nan River (Obs. C2) has decreased. Furthermore, scenario 2 helps to mitigate flood condition along Chao Phraya River (from Obs.C2 to Obs.C2B) better than scenario 1. Streamflow of cases in scenario 2 decreases about $100-200 \mathrm{~m}^{3} / \mathrm{s}$ more than scenario 1.

Before confluence of Yom River and Nan River (From Obs.Y17 to Obs.Y17C), streamflow is lower or similar to the original in scenario 3 . The rate of reduction is inconsistent at Obs. Y17B to Obs.Y17C if compared with other scenarios. After Nan River converges into Yom River (from Obs. N67 to Obs. N67A), all cases started to have streamflow similar to original. The reason might because width of Yom River is narrow, so controlling of flood volume has small impact along Yom River. When it reaches Obs. N67B and Obs. N67C, streamflow became higher than original. This is similar condition as observed in scenario 1. Therefore, flood control at Yom River unable to reduce flood volume at Bung Boraphet area. When Ping River converges into Nan River (from Obs.C2 to Obs. C2B), all 3 cases have streamflow lower than original. The reduction rate of streamflow is similar to the reduction rate of flood volume defined in model.

As a result, flood controlled cannot be done only at Yom River if rate of flood volume to be stored is about $10-30 \%$. If flood control is done only at Yom River, it helps to ease the flood condition after confluence of Ping River and Nan River (from Obs.C2A to Obs.C2C)with small impact only. The reduction rate of streamflow shows minor effect in downstream region. Both results of scenario 1 and scenario 3 shows that both rivers need to be controlled at the same time to know if the flooding condition at Bung Boraphet area could be mitigated.

\subsection{Comparison of Flood Distribution for 3 Scenarios}

Flood distribution areas for these 3 scenarios are used to compare before proposing a suitable flood control condition for study area. Flood distribution area on9 cases for 3 scenarios are focused to see the difference of extent clearly, also to understand effectiveness of flood control at 
each upper reach of rivers. Figure 13(a) and (b), Figure 14(a) and (b), and Figure 15(a) and (b) shows the difference of flood distribution area in 3 scenarios. Upper row in each Figure shows the entire flood distribution area while lower row shows only flood distribution area that affected by each case. Red boxes drawn in each Figure are location of significant changes could be observed. The area is calculated in million $\mathrm{m}^{2}$.
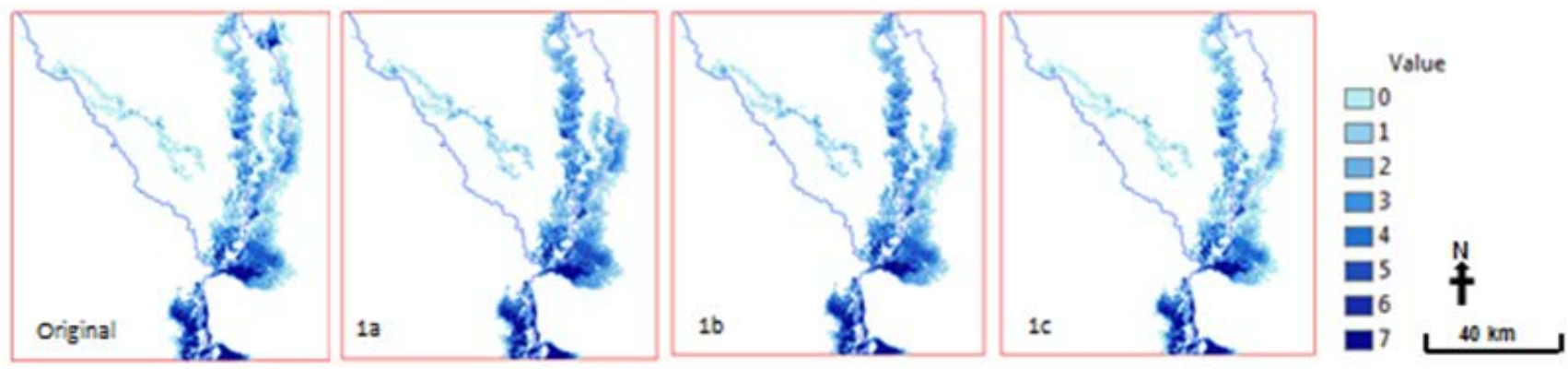

(a) Changes of flood distribution on all rivers in Scenario 1
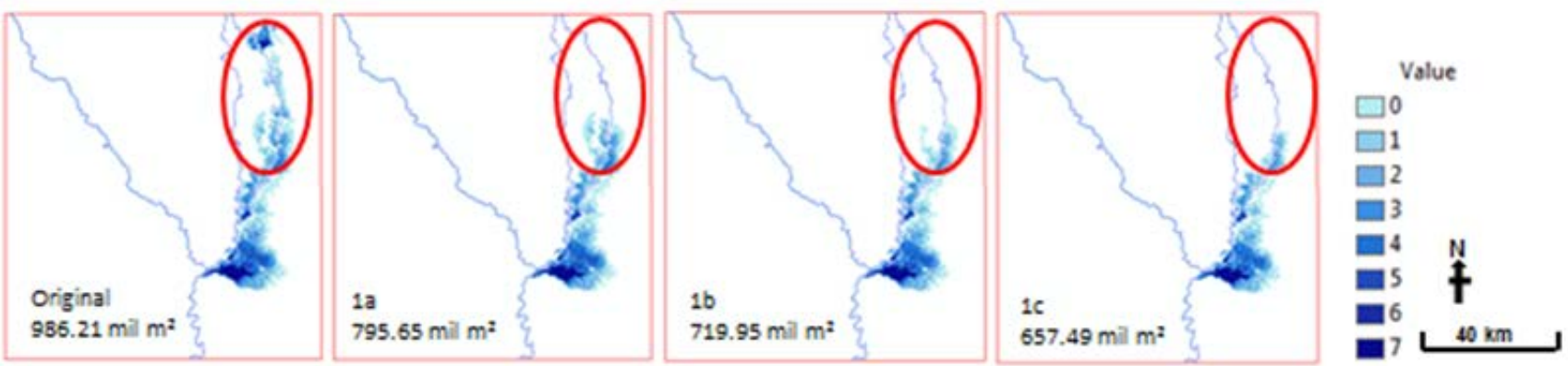

(b) Changes of flood distribution on Nan River

Figure 13. Scenario 1-Changes of flood distribution on October 15, 2011 when flood control at upper reach of Nan River
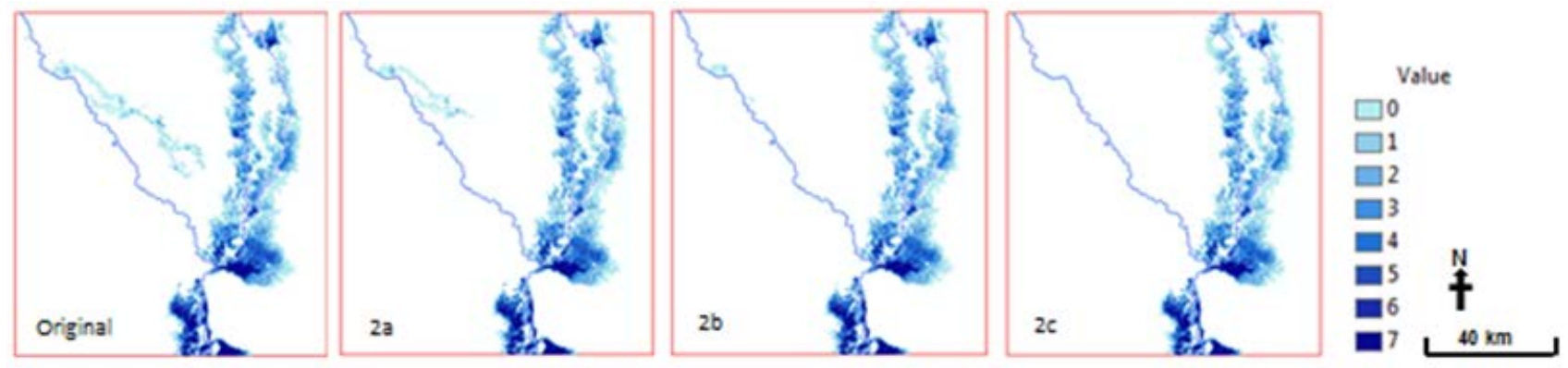

(a) Changes of flood distribution on all rivers in Scenario 2
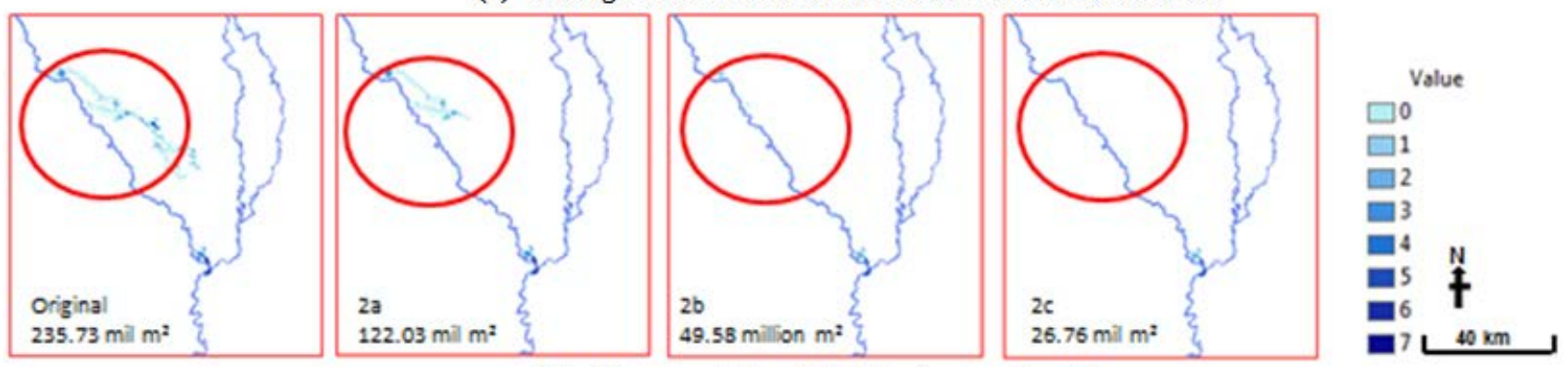

(b) Changes of flood distribution on Ping River

Figure 14. Scenario 2-Changes of flood distribution on October 15, 2011 when flood control at upper reach of Ping River

These 3 scenarios have different results of flood distribution. In scenario 1 (see Figure 7), the flood distribution in case 1 a has $20 \%$ of coverage reduced .In addition, the coverage is reduced to $27 \%$ and $33 \%$ respectively in case $1 \mathrm{~b}$ and case $1 \mathrm{c}$. Thus, each case in scenario 1 helps to reduce flood distribution area about 6$7 \%$. In scenario 2 (see Figure 8), the changes of flood distribution are much wider than scenario 1 . The flood coverage is reduced $50 \%$ in case $2 \mathrm{a}, 80 \%$ in case $2 \mathrm{~b}$ and $90 \%$ in case 2c. It shows each case in scenario 2 able to reduce flood distribution area about $10-30 \%$. In scenario 3 (see Figure 9), the flood distribution changes is smallest compared to scenario 1 and 2 . In case 3a, it reduced only $3 \%$ of coverage, which is minor changes as scenario 1 and scenario 2 shows more than $20 \%$ of reduction when $10 \%$ of flood volume is controlled at upper reach. Case $3 \mathrm{~b}$ and case $3 c$ only reduced $10 \%$ and $12 \%$ of coverage respectively. Each case in scenario 3 able reduces flood distribution area about 2-7\% only. 

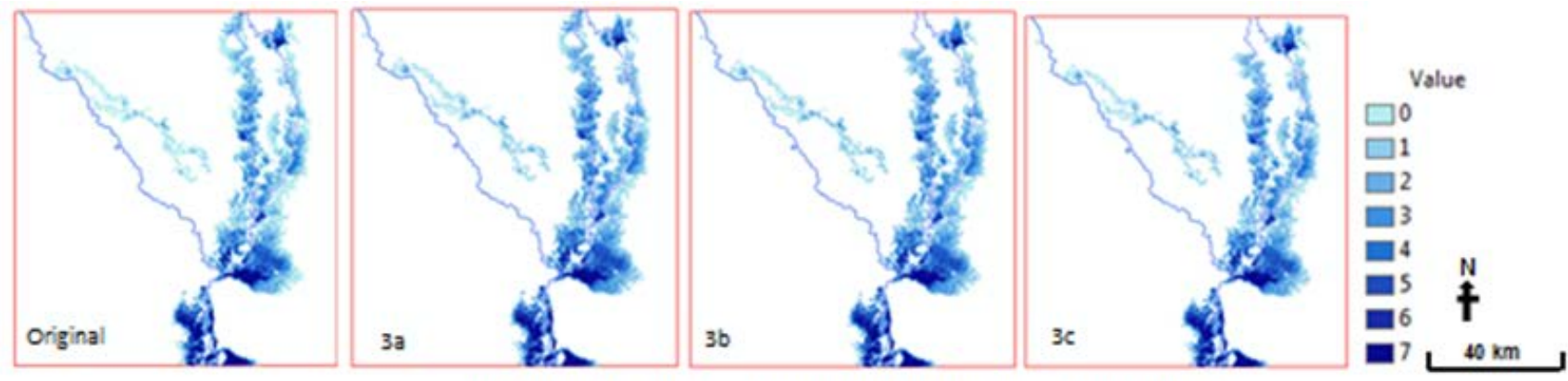

(a) Changes of flood distribution on all rivers in Scenario 3
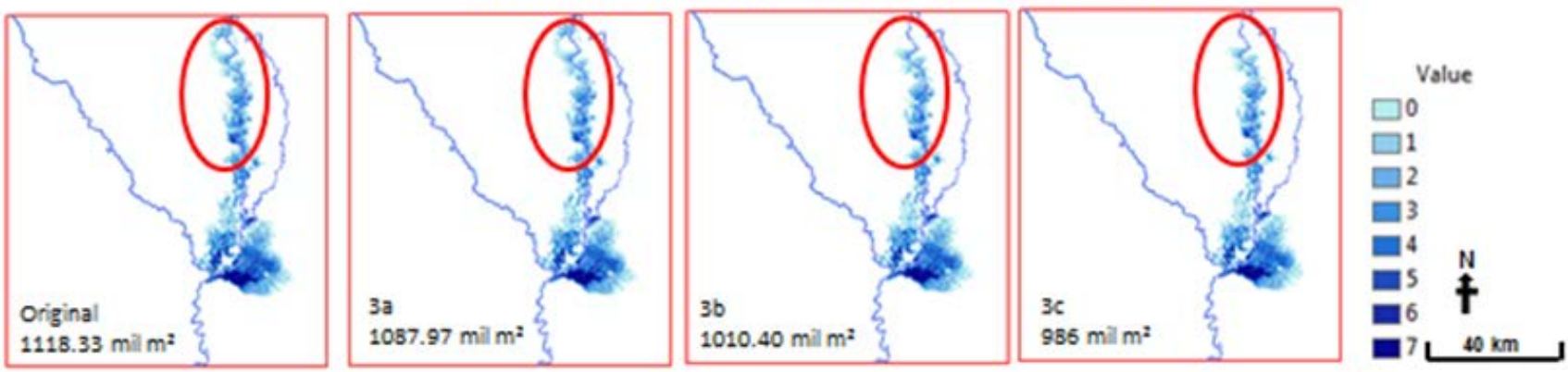

(b) Changes of flood distribution on Yom River

Figure 15. Scenario 3-Changes of flood distribution on October 15, 2011 when flood control at upper reach of Yom River

As a result, flood control at Ping River is most effective to minimize the flood distribution along its river while flood control at Yom River is less effective as it shows only little influence on decreasing the spatial extent of flood along its river.

\section{Proposed Flood Controlling and Discussion}

Considering the effect of 3 scenarios (9 cases) in result of streamflow changes at Obs., reduction in volume and flood distribution area, 2 proposed of flood volume control at upstream rivers arerecommended. There are case $4 \mathrm{a}$ (controlling volume of $20 \%$ at Nan River and $20 \%$ at Yom River) and case $4 \mathrm{~b}$ (controlling volume of $20 \%$ at Nan River, 20\% at Yom River and 10\% at Ping River).

The changes of streamflow for case $4 \mathrm{a}$ and case $4 \mathrm{~b}$ are shown in Figure 16. Streamflow decreases gradually excluded area after Nan River and Yom River converged (from Obs.N67 to Obs.N67C). From Obs.N67 to Obs.N67A, both cases have slightly decreased, then become higher than original at Obs. N67B and Obs.N67C. Case 4a has similar effect with case 4b, particularly before confluence of Ping River and Nan River. After confluence of Ping river and Nan River, which is location from Obs. C2.onwards, case $4 \mathrm{~b}$ helps to reduce about $100-200 \mathrm{~m}^{3} / \mathrm{s}$ more than case 4a along Chao Phraya River.

Before flood peak happened, the streamflow at Nan River and Yom River over its capacity and flow into small streams and flood plains, then the outflow volume returned back to Obs.C2 at flood peak period. Therefore, streamflow at Bung Boraphet area, which is Obs.N67C, has lower streamflow in original case as outflow volume did not return back to this area. On the other hand, when flood volume is controlled at upper reaches of Nan River and Yom River, the streamflow does not over capacity at the upstream and flood volume flow out from rivers only when reaching Bung Boraphet area, result in higher streamflow at Bung Boraphet area. Although flood control at midstream result has higher flood volume at Bung Boraphet area, in contrast, reflooding volume has minimized at Obs.C2 as lower streamflow is indicated in Figure 16.

Figure 17 shows the flood peak period happened from September 21 to October 25, red area is total volume over harmless streamflow limit, which is about 1300 million $\mathrm{m}^{3}$. Although streamflow at both case $4 \mathrm{a}$ and case $4 \mathrm{~b}$ still over harmless streamflow limit at Obs.C2 but the total volume that over harmless streamflow limit is reduced. The calculation of volume is based on equation (1) because the total volume over harmless streamflow limit from simulation (MIKE) is more than total volume from RID data.

$$
V=V_{S}-V_{R}
$$

$$
\begin{array}{ll}
V & : \text { Volume }\left(\mathrm{m}^{3}\right) \\
V_{S} & : \text { Volume of Simulation }\left(\mathrm{m}^{3}\right) \\
V_{R} & : \text { Volume of RID }\left(\mathrm{m}^{3}\right)
\end{array}
$$

In case $4 \mathrm{a}$, the total volume over harmless streamflow limit is decreased to 450 million $\mathrm{m}^{3}$, which means about 850 million $\mathrm{m}^{3}(60 \%)$ volume of over harmless streamflow is reduced. On the other hand, the total volume over harmless streamflow limit in case $4 \mathrm{~b}$ is about 300 million $\mathrm{m}^{3}$, which means about 1000 million $\mathrm{m}^{3}$ (nearly $80 \%$ ) volume of over harmless streamflow is reduced.

Although Obs.N67C has 200 million $\mathrm{m}^{3}$ more than original in the period of September 21 to October 25 for both case $4 \mathrm{a}$ and case $4 \mathrm{~b}$, but the daily streamflow does not go over the harmless streamflow limit for Obs.N67, which is $1500 \mathrm{~m}^{3} / \mathrm{s}$. Most importantly, reflooding volume flows from small streams and flood plains into Obs. C2 are reduced tremendously. As outflow from upstream to small streams has been minimized, the flood volume that over harmless streamflow limit also reduced indirectly. 


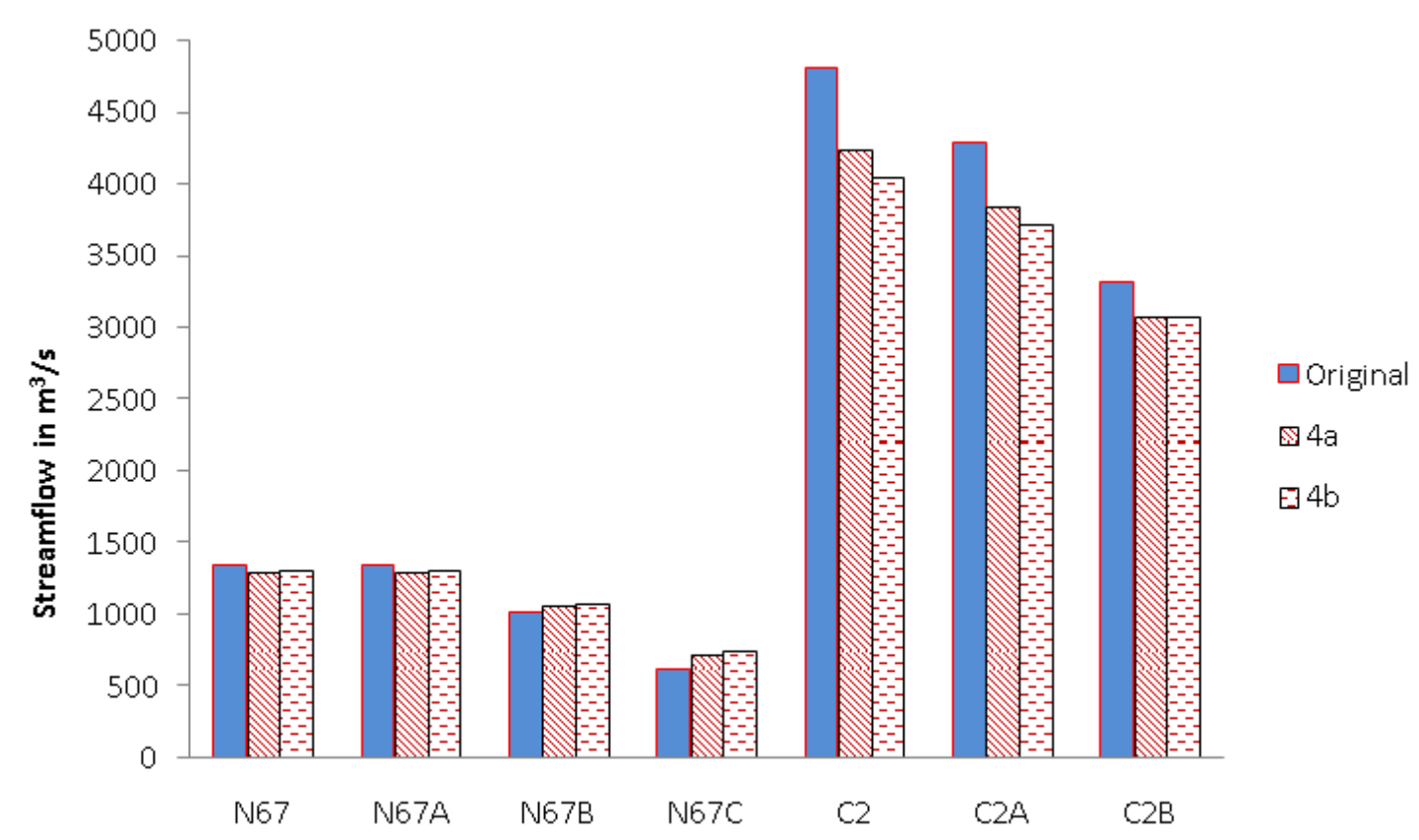

List of Obs. along Rivers after confluence of Nan River and Yom River

Figure 16. Graph indicates changes of streamflow in October after flood controlled as mentioned in Case 4a and Case 4b

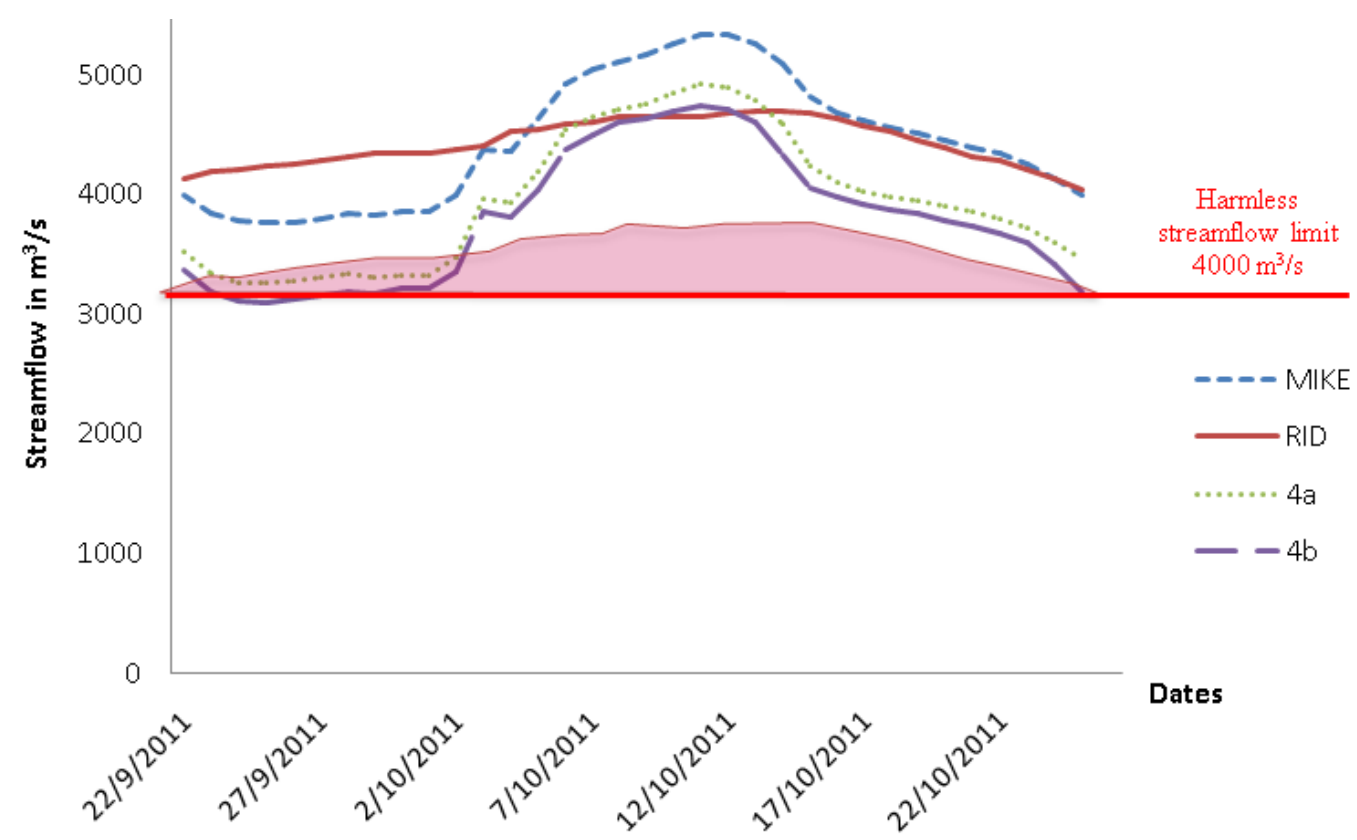

Figure 17. Condition of total streamflow over harmless streamflow limit during flood peak from September 21 to October 25, 2011

\section{Conclusions}

In this study, coupled of $1 \mathrm{D}$ and 2D hydrodynamic model, MIKE FLOOD is used to simulate the 2011 flood generation in midstream of Chao Phraya River Basin. Limited parameters data for model calibration result in model excluded small streams around the main rivers. The validation of model with field survey flood marks and RID data shows good agreement. When flood started from August to October, there is only a difference of 3 hundred million $\mathrm{m}^{3}$ flood volume at gauging station C.2. The flood distribution on October 15 also similar with flood extent of RID.
In order to understand impact of improving existing reservoirs, several scenarios were developed to quantify the flood exposure for different flood protections and management strategies along the Chao Phraya River Basin. Simulation results of flood control shows the controlling of flood volume at upper reaches of Nan River and Yom River are able to reduce the amount of flood volume flows out into small streams and flood plains around rivers, indirectly reduced the amount of flood volume that return to Obs.C2 at Chao Phraya River. It able to reduce $60 \%$ of flood volumethat over harmless streamflow limit. Furthermore, controlling flood volume at upper reaches of Ping River, Nan River and Yom River help to minimize streamflow over harmless limit at Chao Phraya River more effectively. It helps to reduce nearly $80 \%$ of flood 
volume that over harmless streamflow limit as case $4 \mathrm{~b}$ shown.

However, controlling flood volume at upstream of rivers result in higher streamflow at Obs.N67C, Bung Boraphet area. Thus, the landuse planning in this area is needed to be revised and reviewed. Yom River and Nan River in this area need to "create room for river", which means increase the area for flood to spread. Bung Boraphet also could be improved to increase its capacity.

The Thailand master plan to control flood volume at upstream is workable, although there are some weakness such as lack of concrete proposal to compensate farmers in flood retention area and inadequate attention to the complex long-term issues of fragmented water management.

\section{References}

[1] Bates, P.D. and DeRoo, A.P.J. (2000) A simple raster-based model for flood inundation simulation. Journal of Hydrology, 236: 54-77.

[2] Cham, T. C., Mitani, Y., Ikemi, H., Fujii, K. (2013) Flood Hazard Assessment in Upstream Region of Chao Phraya River with GIS, proceeding of Asia Geospatial Conference, Kuala Lumpur, Malaysia.

[3] Chang, T.J., Hsu, M.H., Teng, W.H., Huang, C.J. (2000) A GIS assisted distributed watershed model forsimulating flooding and inundation. Journal of the American Water Resources Association, 36 (5): 975-988.

[4] CTI Engineering International CO.,LTD, INA Corporation. (1999) The Study on Integrated Plan for Flood Mitigation in Chao Phraya River Basin, 2.1-2.2, 2.7-2.11.

[5] Fujii, K., Tsukahara, K., Hayashi, H., Mitani, Y., Ikemi, H., Cham, T.C., Shimatani, Y. (2013)Investigation Report on the Flooding Condition in the Midstream Area of Chao Phraya River During the Thai Flooding in 2011, Journal of Disaster Research, 8:424-431.

[6] Gül, G., Harmancioğlu, N., \& Gül, A. (2010) A combined hydrologic and hydraulic modeling approach for testing efficiency of structural flood control measures. Natural Hazards, 54(2), 245260.

[7] International Centre for Water Hazard and Risk Management (ICHARM), http://www.icharm.pwri.go.jp/.
[8] Komori, D., Nakamura, S., Kigushi, M., Nishijima, A., Yamazaki, D., Suzuki, S., Kawasaki, A ., Oki, K and Oki, T.(2012) Characteristics of the 2011 Chao Phraya River flood in Central Thailand, Hydrological Research Letters, 6: 41-46.

[9] Kourgialas, N., \& Karatzas, G.(2011) Flood management and a GIS modelling method to assess flood-hazard areas-a case study. Journal of Hydrological Sciences, 56 (2): 212-225.

[10] Kwak, Y. J., Park, J.G., Yorozuya, A., Fukami, K. ( 2012) Estimation of Flood Volume in Chao Phraya River Basin, Thailand, from MODIS Images Couppled with Flood Inundation Level. the 32nd annual IGARSS symposium 2012, IEEE Geoscience and Remote Sensing Society.

[11] Oki, T., Komori, D. (2012)Facing the floods in Thailand. Japan Science and Technology Agency. (In Japanese).

[12] Oki, T. (2012) The Chaophraya flood 2011 and flood disaster of Thailand. The University of Tokyo. (In Japanese).

[13] Patro ,S.,Chatterjee, C., Mohanty, S., Singh, R, Raghuwanshi,N.S. (2009) Flood Inundation Modeling using MIKE FLOOD and Remote Sensing Data. Journal Indian Society Remote Sensing, 37: 107-118.

[14] Poaponsakorn, N. and Meethom, P. (2013)Impact of the 2011 Floods, and Flood Management in Thailand, ERIA Discussion Paper Series.

[15] Prajamwong S, Suppataratarn P. (2009) Integrated: Flood Mitigation Management in the Lower Chao Phraya River Basin. Expert Group Meeting on Innovative Strategies Towards Flood Resilient Cities in Asia-Pacific 2009 Meeting Documents.

[16] Remo, J., Carlson, M., \& Pinter, N. (2012) Hydraulic and floodloss modeling of levee, floodplain, and river management strategies, Middle Mississippi River, USA. Natural Hazards, 61(2): 551-575.

[17] Shimakage, J., Yamazaki, F. (2012). Detection of Flooded Areas Following the 2011 Thailand Floods using ASTER Images. $33^{\text {rd }}$ Asian Conference on Remote Sensing 2012. Thailand.

[18] Takeya, K. (2012) JICA's Support to Toward Safe \& Resilient Thailand" through Revising the Comprehensive Flood Management Plan for the Chao Phraya River Basin. Rep. N.p.: JICA.

[19] The Ministry of Finance. (2012) Thai Flood 2011: Rapid Assessment for Resilient Recovery and Reconstruction Planning, Royal Thai Governmental and The World Bank.

[20] Wongsa, S. (2013) 2011 Thailand Flood. Journal of Disaster Research, 8 (3): 380-385. 